ISSN: $1979-7362$

\title{
Desain dan Pengujian Mekanisme Pemindah Benih Padi dengan Metode Hisap
}

\author{
Astuty $^{1}$, Muhammad Tahir Sapsal ${ }^{1}$ dan Salengke ${ }^{1}$ \\ ${ }^{1)}$ Program Studi Teknik Pertanian, Universitas Hasanuddin Makassar
}

\begin{abstract}
ABSTRAK
Kebutuhan tenaga kerja merupakan salah satu penyebab penggunaan atabela sehingga banyak digunakan oleh petani. Dengan menggunakan alat tanam, proses penanaman dapat dilakukan dengan lebih cepat dan tidak membutuhkan banyak tenaga kerja. Alat tanam padi sebaiknya mampu memberikan bibit ataupun benih dengan jumlah 1 batang per titik. Hal ini dapat mengefisienkan penggunaan benih selain dapat meningkatkan produktifitas tanaman padi. Vacuum seeder merupakan alat yang digunakan untuk penyemaian benih, alat ini memanfaatkan tekanan udara untuk menghisap dan menempatkan benih secara tepat 1 benih per titik. Pengembangan dari vacuum seeder adalah needle seeder. Penabur benih ini menghasilkan tingkat presisi yang lebih baik. Namum belum ada penerapan pada benih padi. Penelitian ini bertujuan untuk mengetahui cara penerapan sistem needle seeder dalam menjatah benih padi khususnya pada mekanisme pemindah benih padi. Penelitian ini juga bertujuan untuk mengembangkan sistem alat tanam benih langsung yang telah ada. Berdasarkan pengujian tanpa perlakuan pada posisi benih pada tekanan hisap $61-14 \mathrm{kPa}$ persentase 1 benih terhisap sebanyak $59 \%$, persentase 2 benih sebanyak $34 \%$, persentase 3 benih sebanyak 3\% dan persentase 0 benih terhisap sebanyak 3\%. Pengujian dengan perlakuan pada posisi benih pada tekanan hisap $61-3 \mathrm{kPa}$ diperoleh persentase 1 benih terhisap sebanyak $100 \%$, persentase 2 benih sebanyak $0 \%$ dan persentase 0 benih terhisap sebanyak 0\%. Sedangkan pengujian dengan perlakuan pada wadah pada tekanan hisap 61 $2 \mathrm{kPa}$ persentase 2 benih terhisap sebanyak $4 \%$, persentase 1 benih terhisap sebanyak $96 \%$ dan persentase 0 benih terhisap sebanyak $0 \%$. Sehingga tekanan hisap yang dibutuhkan untuk menarik tepat satu benih adalah pada tekanan hisap $61-2 \mathrm{kPa}$ atau 0,5586 - 0,0196 atm. Dari hasil tersebut dapat disimpulkan bahwa mekanisme pemindah benih padi menghasilkan keluaran yang presisi dengan jumlah benih terhisap 1 benih.
\end{abstract} Kata Kunci: Alat tanam padi, Jumlah benih, Tekanan hisap, Needle seeder, Vacuum
seeder

\section{PENDAHULUAN}

\section{Latar Belakang}

Alat tanam padi telah banyak digunakan. Waktu dan kebutuhan tenaga kerja menjadi penyebabnya. Dengan menggunakan alat tanam, proses penanaman dapat dilakukan dengan lebih cepat dan tidak membutuhkan banyak tenaga kerja. Alat tanam yang sering digunakan yaitu, tipe drum seeder dan transplanter.

Transplanter menggunakan bibit padi yang telah disemai. Namun, Pada transplanter jumlah bibit tertanam tiap lubang 2-4 batang per lubang (Suhendrata, 2013). Dengan jumlah tersebut pertumbuhan tanaman kurang optimal karena tanaman dapat bersaing dalam memperebutkan unsur hara. Begitupun dengan alat tanam benih langsung. Alat tanam ini banyak digunakan oleh petani, karena lebih praktis, tidak membutuhkan penyemaian, tetapi langsung menebarkan benih di lahan. Namun demikian, kendala dari alat tanam ini, yaitu tidak konsistennya jumlah benih yang jatuh. Alat tanam benih langsung menjatuhkan benih dengan jumlah rata-rata 5 bulir per rumpun dengan rentang 1-10 bulir per rumpun (Firdaus, 2014). Keluaran benih dengan jumlah tersebut kurang efisien karena membutuhkan lebih banyak benih yang akan digunakan dalam satu luasan per hektar dan jumlah benih per rumpun tidak seragam.

Vacuum seeder merupakan alat yang digunakan untuk penyemaian benih, alat ini memanfaatkan tekanan udara untuk menghisap dan menempatkan benih secara tepat 1 benih per titik, selanjutnya tekanan 
dikurangi sehingga benih jatuh pada tray semai (Zhang, 2009). Vacuum seeder memiliki beberapa keunggulan yaitu kualitas kerja yang lebih baik, tingkat penjatahan benih lebih tepat dengan tingkat kerusakan benih yang lebih rendah serta kontrol yang lebih baik. Vacuum seeder menggunakan benih lebih sedikit dan dapat mengefisienkan waktu tanam serta meningkatkan hasil produksi (Shaaban, 2009). Pengembangan dari vacuum seeder adalah needle seeder. Mesin ini bekerja dengan sistem penabur menggunakan jarum yang apabila diberi tekanan tinggi dapat menarik benih hingga melekat pada jarum kemudian melepaskan benih ke lokasi tanam dengan menurunkan tekanan. Penabur benih ini menghasilkan tingkat presisi yang lebih baik. Namum belum ada yang menerapkan pada benih padi.

Penelitian ini dilakukanlah untuk menerapkan sistem needle seeder tersebut pada benih padi. Sehingga dapat diterapkan pada atabela maupun pada proses penyemaian padi untuk transplanter.

\section{Tujuan dan Kegunaan}

Penelitian ini bertujuan untuk mengetahui tekanan hisap yang dibutuhkan dan cara penerapan sistem needle seeder dalam menjatah benih padi.

Kegunaan penelitian ini adalah sebagai literatur atau bahan informasi dalam mengembangkan atabela yang telah ada.

\section{METODE PENELITIAN}

\section{Waktu dan Tempat}

Penelitian ini dilaksanakan pada bulan Mei 2017 sampai Oktober 2017. Perancangan unit penghisap dilakukan di Laboratorium Teknik Bengkel Teknologi Pertanian, dan pengujian kinerja unit penghisap dilakukan di Laboratorium Teknik Alsintan, Departemen Teknologi Pertanian, Fakultas Pertanian, Universitas Hasanuddin.

\section{Alat dan Bahan}

Alat yang digunakan pada penelitian ini meliputi alat untuk perakitan unit penghisap dan alat untuk pengujian kinerja unit penghisap. Alat yang digunakan untuk perakitan unit penghisap adalah bor statis dan bor portable, gergaji, gerinda, palu, cut saw, cutter, meteran, pensil dan spidol. Sedangkan alat yang digunakan untuk pengujian kinerja unit penghisap adalah timbangan digital WeiHeng, software CodeVisionAVR, software AVROSPII, sensor MPX5100gp, Atmega16a, LCD 16x2, downloader, kabel sambungan dan soket, adaptor, multimeter, stopwatch dan alat tulis menulis.

Bahan yang digunakan pada penelitian ini yaitu bahan untuk perakitan unit penghisap dan bahan untuk pengujian kinerja unit penghisap. Bahan yang digunakan untuk perakitan unit penghisap adalah akrilik, mata bor diameter $14 \mathrm{~mm}$ dan $12 \mathrm{~mm}$, bearing diameter dalam 10 $\mathrm{mm}$ dan diameter luar $14 \mathrm{~mm}$, besi AS ST$4210 \mathrm{~mm}$, silinder berongga diameter dalam $10 \mathrm{~mm}$, penjepit selang, balok, mur dan baut, paku, lem, spoid, tabung penghisap dan selang diameter dalam 1,5 $\mathrm{mm}$ dan diameter luar $3 \mathrm{~mm}$. Sedangkan bahan yang digunakan untuk pengujian kinerja penghisap adalah benih padi varietas Ciherang.

\section{Tahapan Penelitian}

Penelitian ini dilaksanakan dengan tahapan seperti pada Gambar 1. 


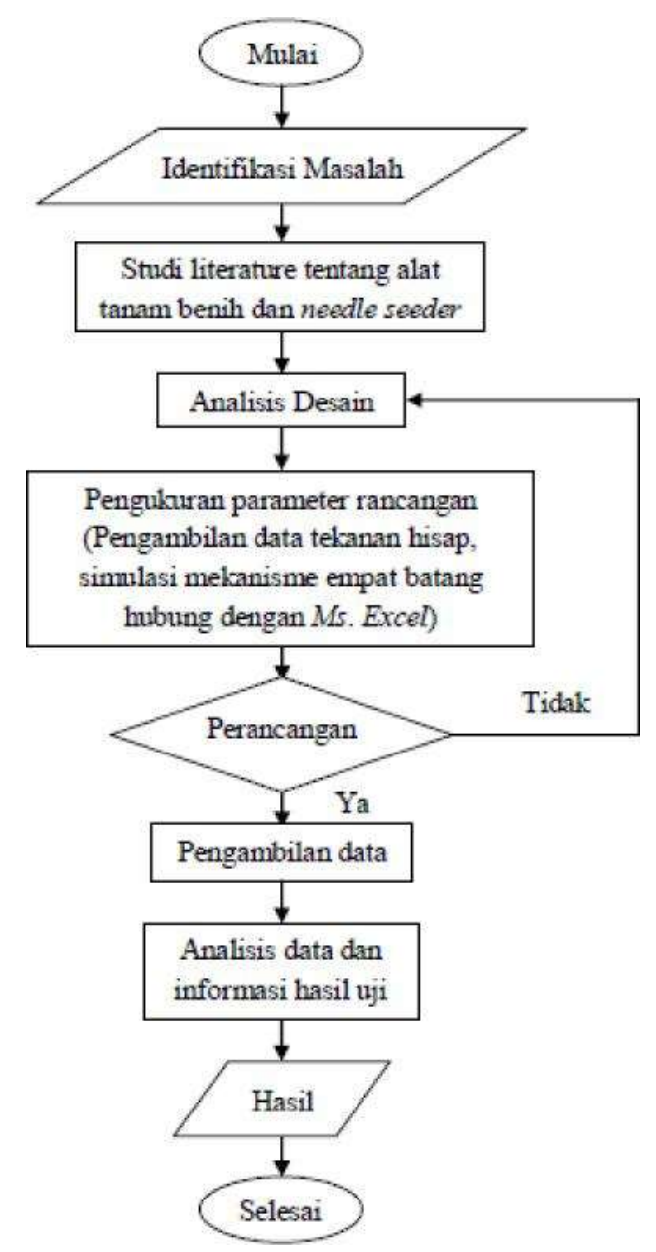

Gambar 1. Bagan Alir Penelitian.

\section{Kriteria Desain}

Mekanisme pemindah benih padi ini dirancang dengan kriteria:

1. Objek yang digunakan berupa gabah kering

2. Mekanisme empat batang hubung dapat bekerja sesuai simulasi.

3. Penghisap digerakkan oleh poros engkol

4. Mekanisme penggerak menggunakan empat batang penghubung.

5. Penelitian awal yang dilakukan, diketahui tekanan hisap yang dibutuhkan agar gabah dapat terhisap adalah pada rentang $44 \mathrm{kPa}$ sampai 2 $\mathrm{kPa}$.

6. Penghisap dipasang pada batang r2 (coupler link).

\section{Analisis Desain Fungsional}

Fungsi utama dari alat ini adalah menghisap benih padi hingga melekat pada selang peghisap. Untuk mencapai fungsi tersebut dibutuhkan komponen berikut:

1. Mekanisme penggerak berfungsi untuk menggerakkan penghisap untuk menghasilkan gaya dorong dan gaya hisap pada penghisap dengan menggunakan mekanisme empat batang hubung jenis crank rocker mechanism.

2. Mekanisme Penghisap berfungsi sebagai penghasil tekanan yang terdiri dari tabung penghisap.

\section{Anaisis Desain Struktural}

Dalam merancang mekanisme pemindah benih padi dengan metode hisap ada beberapa hal yang harus dilakukan yaitu:

1. Penghisap yang digunakan terbuat dari bahan plastik dengan ukuran diameter 1 inci dan panjang $230 \mathrm{~mm}$. Selang penghisap berukuran panjang $75 \mathrm{~mm}$, diameter dalam selang $1,5 \mathrm{~mm}$ dan diameter luar selang $3 \mathrm{~mm}$.

2. Melakukan pengukuran dimensi gabah yang digunakan dimana massa jenis gabah $551,23 \mathrm{~kg} / \mathrm{m}^{3}$, rata-rata berat gabah adalah 0,03 gram, panjang ratarata $4,95 \mathrm{~mm}$, lebar $3,35 \mathrm{~mm}$, tebal 2,62 mm dan kadar air gabah $12 \%$.

3. Melakukan pengukuran tekanan hisap yang dibutuhkan agar gabah dapat terhisap.

4. Menentukan panjang lengan mekanisme empat batang hubung dengan melakukan simulasi di Microsoft Office Excel 2007. Perhitungan mekanisme empat batang hubung dengan mengacu pada persamaan berikut:

a. Untuk mendapatkan nilai radians digunakan persamaan berikut Radians $=\theta_{1} \times \pi / 180$

b. Untuk mendapatkan nilai $X_{s}$ digunakan persamaan berikut $X_{s}=r_{2}+r_{1} x \cos$ radians 
c. Untuk mendapatkan nilai $\mathrm{Y}_{\mathrm{s}}$ digunakan persamaan berikut $Y_{S}=r_{1} x \sin$ radians

d. Untuk mendapatkan nilai phi $(\varphi)$ digunakan persamaan berikut $\varphi=\operatorname{ATAN} 2\left(X_{s} ; Y_{s}\right)$

e. Untuk mendapatkan nilai $S^{2}$ digunakan persamaan berikut $S^{2}=\sqrt{X_{S}^{2}+Y_{S}^{2}}$

f. Untuk mendapatkan nilai psi $(\psi)$ digunakan persamaan berikut $\psi=A \cos \left(S^{2}+r_{3}^{2}-r_{4}^{2}\right) /$ $\left(2 \times \mathrm{S} \times \mathrm{r}_{3}\right)$

g. Menentukan posisi sambungan (joint) A dab B dengan persamaan berikut:

$$
\begin{aligned}
& X A_{0}=0 \\
& Y A_{0}=0 \\
& X A=r 1 x \cos \text { radians } \\
& Y A=r 1 x \sin \text { radians } \\
& X B_{0}=R_{2} \\
& Y B_{0}=0 \\
& X B=X B_{0}+r_{3} x \cos \theta_{14} \\
& Y B=Y B_{0}+r_{3} x \sin \theta_{14}
\end{aligned}
$$

\section{Prosedur Pengujian}

Pengujian mekanisme pemindah benih dilakukan untuk mengetahui hubungan tekanan hisap dan jumlah benih yang terhisap. Tekanan hisap yang dihasilkan diukur dengan menggunakan sensor tekanan MPX5100GP. Program yang akan digunakan untuk pembacaan sensor terlebih dahulu dibuat di CodeVisionAVR yang kemudian didownload ke chip mikrokontroler.

Untuk pembacaan program pada sensor terlebih dahulu dirangkaikan komponen-komponen yang dibutuhkan agar program dapat dijalankan yaitu dengan memasang sensor tekanan MPX5100GP di PORTA pada mikrokontroler dan memasang LCD 16x2 di PORTC kemudian menghubungkan mikrokontroler ke adaptor dengan tegangan 5 Volt. Setelah semuanya terhubung akan ditampilkan nilai tekanan udara $101 \mathrm{kPa}$ atau 1 atmosfer pada LCD $16 \times 2$.
Pengukuran tekanan hisap dilakukan dengan memasang sensor tekanan MPX5100GP diujung tabung penghisap. Penghisap digerakkan dengan memutar engkol pada empat batang penghubung yang akan menghasilkan gerakan hisap dan dorong. Empat batang penghubung dibuat dengan menggunakan akrilik yang berukuran $150 \mathrm{~mm}$ untuk fixed link, 100 mm untuk input link, $160 \mathrm{~mm}$ untuk joint link dan $110 \mathrm{~mm}$ untuk output link. Pada saat penghisap dihisap benih pada wadah akan terhisap dan melekat pada ujung selang penghisap dan akan ditampilkan nilai tekanan hisap di LCD 16x2. Sehingga dapat diketahui berapa nilai tekanan hisap agar benih dapat terhisap.

\section{HASIL DAN PEMBAHASAN}

\section{Skema Alat Pemindah Benih Padi}

Hasil rancangan alat pemindah benih padi yang terdiri dari tabung penghisap, spoid, selang penghisap, wadah benih dan mekanisme empat batang penghubung dapat dilihat pada Gambar 2 dan Gambar 3 berikut ini. Pada alat ini tekanan hisap minimum yang dibutuhkan untuk menarik benih yaitu pada tekanan hisap $2 \mathrm{kPa}$.

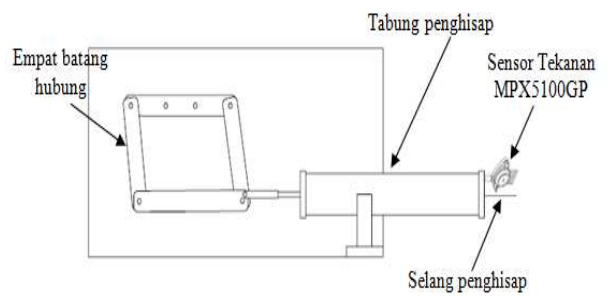

Gambar 2. Skema Alat Pemindah Benih Padi Tampak Depan.

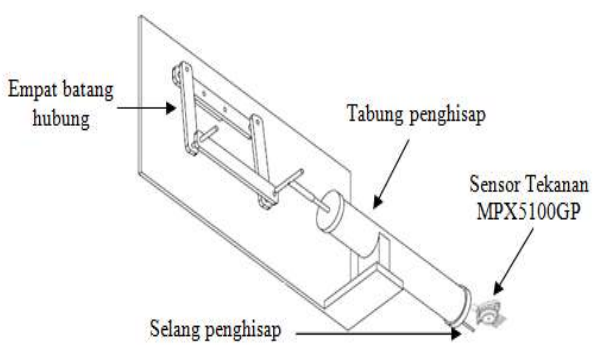

Gambar 3. Skema Alat Pemindah Benih Padi Isometrik. 


\section{Tekanan Hisap yang Dibutuhkan}

Pengukuran tekanan hisap diketahui berdasarkan pembacaan sensor tekanan MPX 5100GP. Hasil pembacaan menunjukkan bahwa kebutuhan tekanan hisap untuk dapat menghisap benih padi adalah pada rentang $2 \mathrm{kPa}-67 \mathrm{kPa}$. Namun untuk memperoleh 1 benih terhisap dibutuhkan tekanan hisap rendah yaitu pada tekanan hisap $<62 \mathrm{kPa}$.

\section{Gaya pada Alat Penghisap}

Pengukuran tekanan hisap menggunakan mekanisme empat batang hubung diperoleh tekanan hisap dalam rentang tersebut yaitu, $2-67 \mathrm{kPa}$. Ada beberapa faktor yang mempengaruhi tekanan hisap diantaranya yaitu tenaga hisap. Dari pengukuran yang telah dilakukan diperoleh gaya yang dibutuhkan untuk menarik penghisap sebesar $1,764 \mathrm{~N}$, sehingga diperoleh tenaga hisap sebesar 0,1764 N.m. Gaya terbesar untuk menggerakkan mekanisme empat batang hubung sebesar 9,353 N, sehingga diperoleh tenaga hisap untuk menarik penghisap sebesar 0,9353 N.m. Perbedaan gaya yang cukup jauh antara penghisap dan mekanisme empat batang hubung dapat terjadi karena penghisap dirancang dan dibuat oleh pabrik sedangkan pada mekanisme empat batang hubung terjadi karena pengukuran yang tidak presisi pada saat perakitan sehingga jarak titik hubung tidak sesuai rancangan.

\section{Pengujian Kinerja Penghisap tanpa Perlakuan pada Posisi Benih}

Gambar 4, menunjukkan bahwa pengujian tanpa perlakuan pada benih yang dilakukan sebanyak 100 kali percobaan diperoleh hasil pada tekanan hisap $14 \mathrm{kPa}-69 \mathrm{kPa}$ dengan jumlah benih terhisap 0 sampai 3 benih.

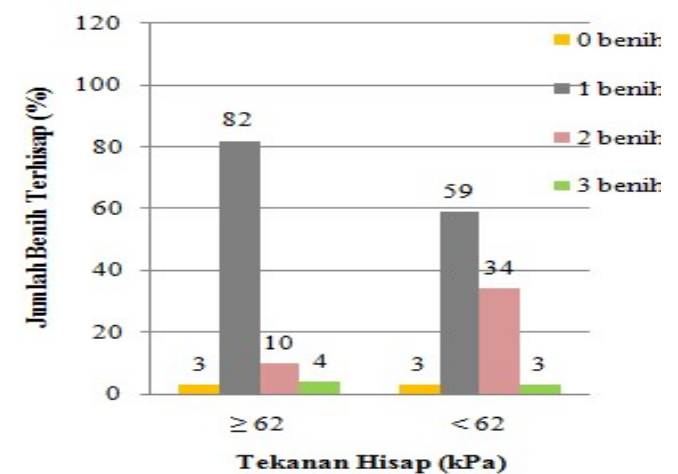

Gambar 4. Grafik Pengujian tanpa Perlakuan pada Posisi Benih.

Gambar 4, menunjukkan pada tekanan hisap $\geq 62 \mathrm{kPa}$ persentase 1 benih yang terhisap sebanyak $82 \%$, persentase 2 benih sebanyak $10 \%$, persentase 3 benih sebanyak $4 \%$ dan persentase 0 benih terhisap sebanyak 3\%. Pada tekanan hisap $<62 \mathrm{kPa}$ persentase 1 benih terhisap sebanyak 59\%, persentase 2 benih sebanyak $34 \%$, persentase 3 benih sebanyak $3 \%$ dan persentase 0 benih terhisap sebanyak 3\%. Hasil tersebut kurang presisi karena total jumlah benih terhisap lebih dari 1 benih lebih banyak yaitu $22 \%$. Dimana dengan hasil tersebut penggunaan benih tidak efisien dan pertumbuhan anakan krurang produktif. Banyaknya benih yang terhisap lebih dari 1 disebabkan oleh posisi benih yang vertikal pada wadah sehingga ujung selang penghisap tidak tetutup rapat jika bertemu dengan ujung benih karena terdapat celah atau ruang yang menyebabkan adanya peluang untuk benih terhisap lebih dari 1 benih. Jarak yang tidak tetap antara selang penghisap dan benih juga mempengaruhi hasil benih terhisap dimana apabila benih dan selang penghisap bersentuhan langsung menyebabkan benih terhisap lebih dari 1 sehingga diperlukan perlakuan pada posisi benih.

\section{Pengujian Kinerja Penghisap dengan Perlakuan Pada Posisi Benih}

Gambar 5, menunjukkan bahwa pengujian pada benih yang dilakukan 
sebanyak 150 kali percobaan menghasilkan tekanan hisap $\geq 62 \mathrm{kPa}$ dan diperoleh persentase 1 benih yang terhisap sebanyak $86 \%$, persentase 2 benih sebanyak $8 \%$ dan persentase 0 benih terhisap sebanyak 6\%. Sedangkan pada tekanan hisap rendah yaitu $<62 \mathrm{kPa}$ diperoleh persentase satu benih terhisap sebanyak $100 \%$, persentase 2 benih sebanyak $0 \%$ dan persentase 0 benih terhisap sebanyak $0 \%$. Hal tersebut menunjukkan bahwa pada tekanan hisap rendah yaitu $<62 \mathrm{kPa}$ hasil yang diperoleh lebih presisi dimana benih dapat terhisap tepat 1 benih sesuai dengan hasil yang diinginkan. Hal tersebut sesuai dengan pernyataan Shaaban (2009) bahwa vacuum seeder memiliki tingkat penjatahan benih lebih tepat dengan tingkat kerusakan benih yang lebih rendah.

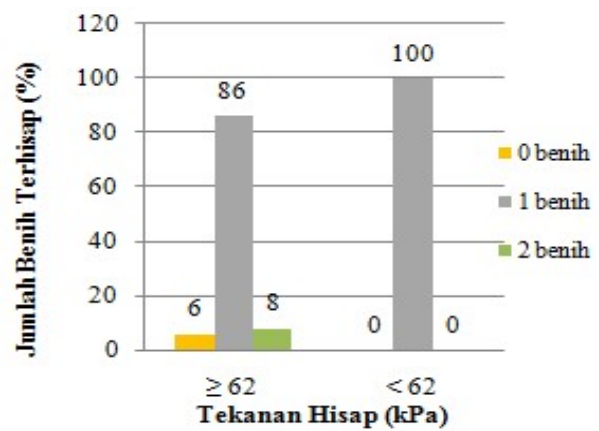

Gambar 5. Grafik Pengujian dengan Perlakuan pada Posisi Benih.

Gambar 5, diketahui bahwa jumlah benih yang dapat terhisap berubah berdasarkan tekanan hisapnya dimana semakin rendah tekanan hisap yang diberikan maka semakin rendah daya hisapnya sehingga benih yang dapat terhisap adalah tepat 1 benih yang merupakan hasil yang ingin dicapai. Semakin tinggi tekanan hisap yang diberikan maka semakin tinggi pula daya hisapnya sehingga jumlah benih yang dapat terhisap bisa mencapai 2 sampai 3 benih.

\section{Pengujian Kinerja Penghisap dengan Perlakuan pada Wadah}

Gambar 6, menunjukkan bahwa pada pengujian dengan perlakuan pada wadah yang dilakukan sebanyak 100 kali percobaan dengan jumlah benih yang digunakan sebanyak 5 gram diperoleh hasil dengan tekanan hisap $<62 \mathrm{kPa}$ dimana persentase benih yang dapat terhisap 2 benih sebanyak $4 \%$, persentase benih yang dapat terhisap tepat 1 benih sebanyak $96 \%$ dan persentase benih terhisap 0 benih sebanyak $0 \%$. Dari hasil pengujian diketahui bahwa perlakuan tersebut masih terdapat kekurangan sehingga hasil yang diperoleh tidak $100 \%$.

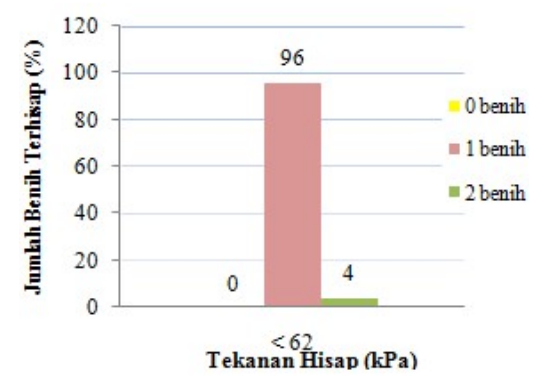

Gambar 6. Grafik Pengujian dengan Perlakuan pada Wadah.

Pengujian dengan perlakuan pada posisi benih (Gambar 15), dengan tekanan hisap tinggi $\geq 62 \mathrm{kPa}$ yang menunjukkan hasil yang kurang presisi yaitu persentase 2 benih terhisap sebanyak $8 \%$ sedangkan pada pengujian dengan perlakuan pada wadah (Gambar 16), diperoleh persentase 2 benih terhisap sebanyak 4\%. Jika dilihat dari persentase 2 benih terhisap maka dapat diketahui bahwa pengujian dengan perlakuan pada wadah memperoleh hasil lebih presisi.

Atabela tipe drum yang banyak digunakan menghasilkan keluaran dengan jumlah bulir padi rata-rata adalah 4,61 - 5 bulir. Jumlah benih padi maksimal yang jatuh adalah 10 bulir, sedangkan jumlah benih padi minimal yang jatuh adalah 1 bulir. Jumlah benih padi per rumpun yang jatuh masih terlalu banyak bila dibandingkan dengan yang diharapkan (Firdaus, 2014). Sedangkan pada 
mekanisme pemindah benih padi dengan metode hisap jumlah bulir padi rata-rata yang dihasilkan adalah 1 bulir dengan persentase $96 \%$ dan jumlah bulir padi maksimal yang dihasilkan adalah 3 dengan persentase $3 \%$. Hasil tersebut menunjukkan bahwa mekanisme pemindah benih padi yang dibuat memperoleh hasil yang lebih presisi dibandingkan dengan atabela tipe drum.

Pengujian dengan perlakuan pada posisi benih masih terdapat kekurangan yaitu benih disusun satu per satu sehingga tidak efisien dalam penggunaan waktu jika diterapkan di lahan. Oleh karena itu, dilakukan pengujian dengan perlakuan pada wadah dimana wadah dimiringkan $30^{\circ}$ sehingga apabila benih dijatuhkan benih dapat tersusun secara langsung. Namun pada perlakuan tersebut terdapat jumlah benih terhisap lebih dari 1 bulir sebanyak 4\%. Oleh karena itu dibutuhkan mekanisme penggetar pada wadah benih agar hasil yang diperoleh lebih presisi.

\section{Jumlah Gabah Terhisap tanpa Perlakuan pada Posisi Benih}

Gambar 7, pengujian kinerja penghisap tanpa perlakuan pada posisi benih memperoleh hasil yang kurang presisi dengan persentase terhisapnya tepat 1 benih sebanyak $75 \%$, persentase lebih dari 1 benih terhisap sebanyak $22 \%$ dan 0 benih terhisap sebanyak 3\%. Hasil yang kurang presisi disebabkan oleh posisi benih yang tidak teratur sehingga peluang benih terhisap lebih dari 1 lebih banyak. Jumlah benih yang digunakan pada saat pengujian tanpa perlakuan pada posisi benih sebanyak 20 gram sehingga benih yang terhisap lebih dari 1 bulir karena benih yang berada pada radius penghisapan lebih banyak dan menyebabkan benih disekitarnya ikut terhisap.

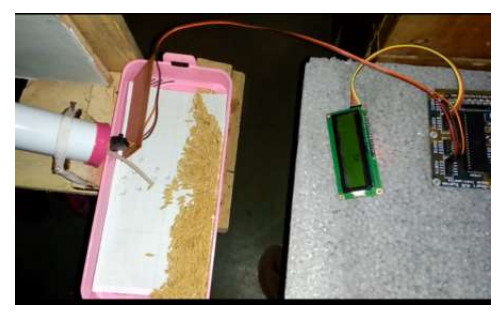

Gambar 7. Jumlah Gabah Terhisap tanpa Perlakuan pada Posisi Benih.

\section{Jumlah Gabah Terhisap dengan Perlakuan pada Posisi Benih}

Gambar 8, pengujian kinerja penghisap dengan perlakuan pada posisi benih memperoleh hasil yang cukup presisi dengan persentase terhisapnya tepat 1 benih sebanyak 91\%, lebih dari 1 benih sebanyak $5 \%$ dan 0 benih sebanyak $4 \%$. Persentase 1 benih terhisap sebanyak $100 \%$ selain dipengaruhi oleh tekanan rendah juga dipengaruhi oleh jumlah benih yang digunakan pada saat pengujian. Pada saat pengujian dengan memberikan perlakuan pada posisi benih padi, jumlah benih yang digunakan sebanyak 1 gram, benih disusun melintang sehingga pada saat dihisap benih yang terhisap tepat satu benih. Hal tersebut dapat terjadi karena jumlah benih yang digunakan tidak banyak sehingga benih yang berada pada radius penghisapan tidak lebih dari 2 bulir benih.

Hasil pengujian menunjukkan bahwa pengujian dengan perlakuan pada posisi benih memperoleh hasil yang lebih presisi dibandingkan dengan pengujian tanpa perlakuan pada posisi benih. Dapat diketahui pula selisih kepresisian antara pengujian tanpa perlakuan pada posisi benih dan pengujian dengan perlakuan pada posisi benih adalah $16 \%$ hal tersebut menunjukkan bahwa pengujian dengan perlakuan pada benih lebih baik dengan tingkat kepresisian dalam menghasilkan 1 benih terhisap yang lebih tinggi. 


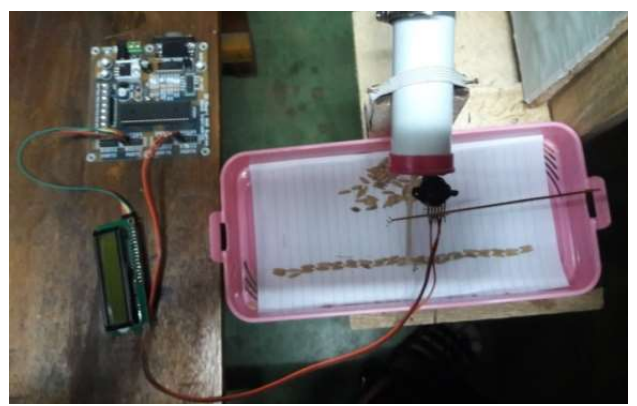

Gambar 8. Jumlah Gabah Terhisap dengan Perlakuan pada Posisi Benih.

\section{Posisi Benih}

Hasil Gambar 4 dan Gambar 5, dapat dilihat bahwa persentase jumlah benih terhisap tepat 1 benih lebih banyak diperoleh pada Gambar 15, yaitu pengujian dengan perlakuan pada posisi benih dengan persentase $91,3 \%$. Sedangkan pada Gambar 14, pengujian tanpa perlakuan pada posisi benih diperoleh hasil sebanyak $75 \%$.

Posisi benih pada saat pengujian sebaiknya melintang (horisontal) untuk menghindari terhisapnya benih dengan jumlah lebih dari 1 benih. Oleh karena itu, dilakukan pengujian dengan perlakuan pada wadah dimana wadah dimiringkan sehingga apabila benih dijatuhkan benih dapat tersusun secara langsung. Namun pada perlakuan tersebut masih terdapat jumlah benih terhisap lebih dari 1 benih sebanyak 4\% sesuai hasil pengujian pada Gambar 16.

Persentase jumlah benih terhisap tepat 1 benih ditunjukkan pada pengujian dengan perlakuan pada wadah yaitu sebesar 96\%. Sedangkan pada pengujian dengan perlakuan pada benih diperoleh persentase jumlah benih terhisap tepat 1 benih sebesar 91,3\%. Hal tersebut menunjukkan bahwa pengujian dengan perlakuan pada wadah benih memperoleh hasil yang lebih baik.

Pada hasil penelitian dapat dilihat bahwa alat tersebut dapat bekerja sesuai dengan rancangan karena mampu menghasilkan persentase jumlah benih yang terhisap yaitu 1 bulir benih sebesar $96 \%$. Dengan jumlah tersebut penggunaan benih pada alat tanam benih langsung dapat diefisienkan dan meningkatkan produktifitas tanaman. Hal tersebut sesuai dengan penyataan (Muyassir, 2012) yang menyatakan bahwa ada kecenderungan penggunaan jumlah bibit 1 sampai 2 batang per rumpun yang dipergunakan akan memberikan hasil lebih tinggi bila dibandingkan dengan penggunaan bibit lebih dari 2 batang per rumpun.

Salah satu cara yang dapat meningkatkan nilai tambah produktivitas tanaman padi adalah dengan penerapan mekanisasi pertanian. Dari tujuannya penerapan mekanisasi pertanian dimaksudkan untuk menangani pekerjaan yang tidak mungkin dilakukan secara manual, meningkatkan produktivitas, efisien dalam penggunaan input produksi, meningkatkan kualitas dan produktivitas serta memberikan nilai tambah bagi penggunanya. Oleh karena itu dirancang alat pemindah benih padi dengan menerapkan sistem needle seeder untuk menghasilkan jumlah benih 1 bulir tiap lubang tanam. Namun untuk mengatasi terhisapnya benih dengan jumlah lebih dari 1 benih dibutuhkan mekanisme penggetar pada wadah agar hasil yang diperoleh lebih presisi. Hal tersebut sesuai pernyataan Build \& Lowson (2014) bahwa needle seeder presisi ini menghisap benih yang berasal dari wadah bergetar dan akan memberikan peningkatan akurasi dalam menabur benih.

Dengan menggunakan metode penghisap, tingkat kerusakan pada benih lebih rendah bila dibandingkan dengan penggunaan atabela tipe drum dimana tingkat kerusakan benih lebih tinggi yang disebabkan oleh gesekan antara benih dengan penjatah. Hal ini sesuai dengan pernyataan Zhang (2009) bahwa, vacuum seeder menggunakan jarum presissi mampu memenuhi kebutuhan pembenihan presisi dan tingkat kerusakan benih lebih rendah. 


\section{Pengaruh Kerapatan Permukaan Benih pada Selang Penghisap dengan Perbedaan Tekanan Hisap}

Tekanan hisap yang diperolah pada pengujian tidak konstan atau berbeda-beda (dapat dilihat pada lampiran 1, lampiran 2, dan lampiran 3). Hal tersebut dipengaruhi oleh kerapatan permukaan benih pada selang penghisap. Ada beberapa kondisi yang terjadi pada saat pengujian, diantaranya lubang selang penghisap tertutup rapat oleh permukaan benih dimana saat dihisap benih melekat sempurna sehingga tidak ada celah yang dapat dilalui udara untuk masuk ke ruang vakum yang menyebabkan tekanan hisap yang dihasilkan menjadi rendah, dan kondisi dimana lubang selang penghisap tidak tertutup rapat atau benih tidak melekat sempurna sehingga ada celah yang dapat dilalui udara yang menyebabkan tekanan hisap menjadi tinggi dan berbeda dengan pada kondisi dimana permukan benih melekat sempurna pada selang penghisap. Oleh karena itu tekanan hisap pada setiap percobaan tidak konstan yang disebabkan oleh adanya perbedaan kondisi yang terjadi pada saat pengujian.

\section{Pengaruh Jumlah Benih Terhisap dengan Jarak Benih pada Selang Penghisap}

Terhisapnya lebih dari 1 benih juga dipengaruhi oleh jarak benih pada selang penghisap. Berdasakan Gambar 19 dan Gambar 20, dapat diketahui bahwa pada jarak $1 \mathrm{~mm}$ benih dapat terhisap tepat 1 benih sedangkan pada jarak $2 \mathrm{~mm}$ ada beberapa percobaan dimana benih tidak terhisap dan pada jarak $3 \mathrm{~mm}, 4 \mathrm{~mm}$ dan 5 $\mathrm{mm}$ tidak ada benih yang terhisap. Terhisapnya lebih dari 1 benih dapat terjadi karena posisi benih antara satu dengan yang lain saling berdekatan dan tidak ada jarak antara benih dengan selang penghisap pada saat menghisap (benih bersentuhan dengan selang penghisap) sehingga apabila ada 2 atau 3 benih yang saling berdekatan maka lubang pada selang penghisap tertutup rapat dan menyebabkan tekanan hisap menjadi tinggi. Oleh karena itu jumlah benih terhisap lebih dari satu.

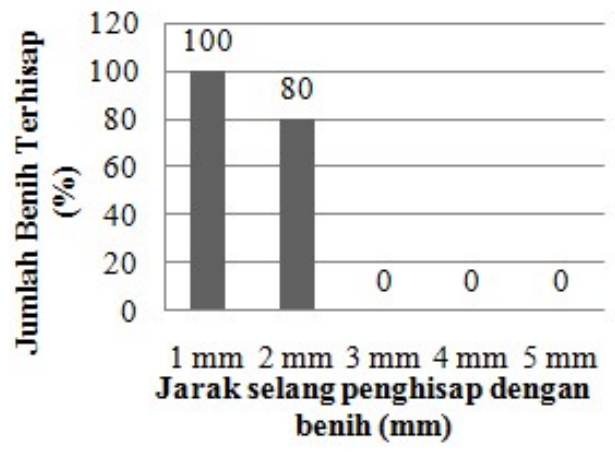

Gambar 19. Pengujian Pengaruh Jumlah Benih Terhisap dengan Jarak Benih pada Selang Penghisap Menggunakan 1 Benih.

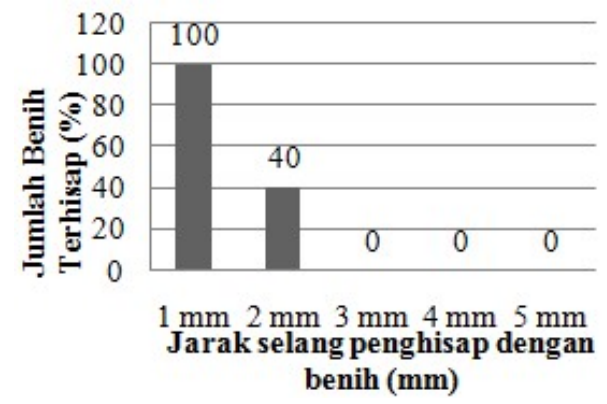

Gambar 20. Pengujian Pengaruh Jumlah Benih Terhisap dengan Jarak Benih pada Selang Penghisap Menggunakan 2 Benih.

Jarak antara benih dengan selang penghisap mempengaruhi banyaknya jumlah benih tertarik dimana hasil pengujian menunjukkan bahwa untuk menghasikan 1 benih tertarik dibutuhkan jarak yang konsisten antara benih dengan selang penghisap yaitu pada jarak $1 \mathrm{~mm}$.

\section{KESIMPULAN DAN SARAN}

\section{Kesimpulan}

Kesimpulan yang diperoleh dari penelitian ini sebagai berikut:

1. Tekanan hisap yang dibutuhkan untuk menarik gabah adalah pada tekanan hisap $<62 \mathrm{kPa}$ atau $<0,6076 \mathrm{~atm}$. 
2. Mekanisme yang dibuat mampu menghasilkan tekanan hisap yang dibutuhkan untuk menghisap gabah.

3. Mekanisme yang dibuat mampu menghasilkan tekanan hisap yang dibutuhkan untuk menghisap gabah.

4. Akurasi penjatah dapat ditingkatkan jika posisi benih melintang terhadap penghisap dengan selisih satu benih terhisap sebanyak $16 \%$.

5. Jarak benih dengan selang penghisap untuk menghasilkan benih terhisap tepat satu benih yaitu pada jarak $1 \mathrm{~mm}$.

\section{Saran}

Wadah untuk benih sebaiknya dibuatkan mekanisme penggetar untuk menghasilkan posisi benih yang teratur secara otomatis sehingga benih yang dapat terhisap tepat 1 benih dan hasil yang diperoleh lebih presisi.

\section{DAFTAR PUSTAKA}

Bouldin \& Lowson. 2014. Precision Needle Seeder. United State of America.

Firdaus, Jonni. 2013. Desain Dan Pengujian Alat Tanam Benih Langsung (Atabela) Jajar Legowo Hemat Energi Pada Padi Sawah. Balai Pengkajian Teknologi Pertanian. Sulawesi Tengah.

Muyassir. 2012. Efek Jarak Tanam, Umur dan Jumlah Bibit Terhadap Hasil Padi Sawah (Oryza sativa L.). Universitas

Shaaban, UA. 2009. Development of $A$ Vacuum Precision Seeder Prototype For Onion Seeds. Benha University. Moshtohor.

Suhendrata, Tota. 2013. Prospek Pengembangan Mesin Tanam Pindah Bibit Padi Dalam Rangka Mengatasi Kelangkaan Tenaga Kerja Tanam Bibit Padi. Balai Pengkajian Teknologi Pertanian. Jawa Tengah.
Zhang, Xiaohui., Song, Jiannong. 2009. Design and research on rice precision needle-like vacuum seeder. China Agricultural University. Beijing. 